\title{
Variation in CDKAL1 Gene Is Associated With Therapeutic Response to Sulphonylureas
}

\author{
Z. SCHRONER ${ }^{1}$, M. JAVORSKÝ ${ }^{1}$, J. HALUŠKOVÁ ${ }^{2}$, L. KLIMČÁKOVÁ ${ }^{2}$, \\ E. BABJAKOVÁ ${ }^{1}$, M. FABIANOVÁ ${ }^{1}$, E. SLABÁ ${ }^{2}$, M. KOZÁROVÁ ${ }^{1}$, I. TKÁČ \\ ${ }^{1}$ Department of Internal Medicine 4, Faculty of Medicine, Šafárik University, Košice, Slovakia, \\ ${ }^{2}$ Department of Medical Biology, Faculty of Medicine, Šafárik University, Košice, Slovakia
}

Received May 24, 2011

Accepted December 9, 2011

On-line January 31, 2012

\section{Summary}

The aim of the present pilot pharmacogenetic study was to analyse quantitative effects of sulphonylurea treatment in addition to metformin on parameters of glycemic control with respect to CDKAL1 genotypes in patients with type 2 diabetes. Effect of 6-month sulphonylurea therapy on glycemic control according to CDKAL1 genotypes was evaluated in 101 patients with type 2 diabetes who failed to achieve glycemic control on metformin monotherapy. CDKAL1 rs7756992 polymorphism was determined by melting curve analysis of small amplicon following real-time PCR. After sulphonylurea treatment fasting plasma glucose (FPG) levels were significantly different $(p=0.045)$ among three CDKAL1 genotype groups (AA: $n=49 ; A G: n=36$; GG: $n=16$ ). In a dominant genetic model, carriers of the $G$-allele ( $A G+G G, n=52$ ) achieved significantly lower FPG levels in comparison with patients with the AA genotype (6.90土1.08 vs. $7.48 \pm 1.12 \mathrm{mmol} / \mathrm{l}, \mathrm{p}=0.013)$. Consequently, adjusted $\triangle \mathrm{FPG}$ was significantly higher in the $A G+G G$ compared to the $A A$ group (1.48 \pm 1.51 vs. $1.02 \pm 1.33 \mathrm{mmol} / \mathrm{l}, \mathrm{p}=0.022)$. Similar trend was observed for $\mathrm{HbA}_{1 \mathrm{c}}$ levels, but the difference between the genotype groups did not reach the level of statistical significance. Relatively small number of included patients is a limitation of the present study. In conclusion, our results suggest that the magnitude of FPG reduction after 6-month sulphonylurea treatment in patients with type 2 diabetes is related to the variation in CDKAL1.

\section{Key words}

Pharmacogenetics • Sulphonylureas • CDKAL1 • Glycemic control - Type 2 diabetes

\section{Corresponding author}

I. Tkáč, Department of Internal Medicine 4, L. Pasteur University Hospital, Rastislavova 43, 04190 Košice, Slovakia. E-mail: ivantkac@lf.upjs.sk

\section{Introduction}

Type 2 diabetes is a disease with significant genetic predisposition. In recent years, more than 40 genes associated with type 2 diabetes were identified by genomewide association studies (GWAS) (Wheeler and Barroso 2011). CDKAL1 was identified as a susceptibility gene for type 2 diabetes through five subsequent GWAS in several population cohorts of European and Asian ancestry (Saxena et al. 2007, Scott et al. 2007, Steinthorsdottir et al. 2007, Zeggini et al. 2007, Takeuchi et al. 2009).

CDKAL1 (cyclin-dependent kinase 5 (CDK5) regulatory subunit-associated protein 1-like 1) encodes a $65-\mathrm{kD}$ protein (CDKAL-1). Although the function of CDKAL-1 is still unclear, this protein is similar to cyclindependent kinase 5 regulatory subunit-associated protein 1 (CDK5RAP-1), which is expressed in neuronal tissues, and inhibits CDK5 activity by binding to the CDK5 activator p35. CDK5 has been shown to blunt insulin secretion in response to glucose and to play a permissive role in the decrease of insulin gene expression, suggesting that CDKAL-1 plays a role in $\beta$-cell function by inhibiting activity of CDK5. However, at the present time, all molecular mechanisms through which CDKAL-1 modulates insulin release in pancreatic $\beta$-cells are unknown (Dehwah et al. 2010, Ohara-Imaizumi et al. 2010). 
The first single nucleotide polymorphism (SNP) in CDKAL1 reported to have been associated with type 2 diabetes was rs7756992 $\mathrm{A}>\mathrm{G}$ which resides in intron 5. Functional studies showed its relationship to impaired insulin secretion (Steinthorsdottir et al. 2007). Another polymorphism in CDKAL1 rs7754840 was shown to be related to impaired insulin processing (Kirchhoff et al. 2008) and secretion (Palmer et al. 2008, Stančáková et al. 2009). Some authors suggest that pathomechanism leading to the development of type 2 diabetes in the presence of risk variants of this gene is mediated by impaired regulation of the cell cycle (Ridderstrale et al. 2009).

Recommended initial therapeutic interventions in type 2 diabetes include lifestyle changes and pharmacotherapy with metformin (Nathan et al. 2008). In patients with metformin monotherapy failure, sulphonylureas are frequently prescribed as a second line treatment (Nathan et al. 2008). Sulphonylureas act as insulin secretagogues through the stimulation of insulin secretion via the sulphonylurea receptor 1 (SUR-1) in pancreatic $\beta$-cells (Gribble and Reimann 2003). Considerable interindividual variation in the glucoselowering response to sulphonylureas likely reflects variations in the $\beta$-cell secretory reserve, and may relate to variations in genes involved in regulating $\beta$-cell function. Gene variants in ABCC8 (Zhang et al. 2007, Feng et al. 2008) and in TCF7L2 (Pearson et al. 2007, Schroner et al. 2011) were reported to be associated with sulphonylurea effect so far.

Since genetic variations in CDKAL1 were reported to have been associated with $\beta$-cell function (Steinthorsdottir et al. 2007), we hypothesised that the magnitude of sulphonylurea treatment effect might be related to the CDKAL1 genotype. Therefore, the aim of the present pilot pharmacogenetic study was to analyse quantitative effects of sulphonylurea treatment in addition to metformin on parameters of glycemic control with respect to $C D K A L 1$ genotypes in patients with type 2 diabetes.

\section{Patients and Methods}

Type 2 diabetes was diagnosed according to criteria of the American Diabetes Association. The study was conducted in a university hospital setting. One hundred and one patients (50 males and 51 females, mean age $61.8 \pm 10.1$ years) were recruited from three outpatient clinics. Patients were eligible for the study if they were on previous metformin monotherapy for at least 6 months, and failed to maintain HbAlc $<7.0 \%$ on maximal tolerated doses of metformin at two consecutive visits within a three month period. Inclusion criteria were HbAlc of 7.0-11.0\%, age 35-70 years, and body mass index (BMI) $20-35 \mathrm{~kg} / \mathrm{m}^{2}$. Patients with malignancies, endocrine disorders, chronic renal failure, severe liver disease, systemic inflammatory disease and corticosteroid treatment were excluded. The ethical approval for this study was obtained from L. Pasteur University Hospital Review Board. All participating subjects gave a written consent to the study.

At the baseline visit, anthropometric data and both diabetes and metformin treatment duration were recorded. Blood samples were taken for biochemical measurements and genotyping, and sulphonylurea treatment was started with $25-50 \%$ of maximum approved dose of the specific sulphonylurea. During the interim visit(s), the doses of sulphonylureas could have been changed based on the results of blood glucose selfmonitoring. Mean sulphonylurea dose prescribed on the last visit before the end of 6-month period was $47 \pm 2 \%$ of maximum approved dose for the concrete drug. Measurements of body weight, HbA1c, FPG and blood lipids were repeated after 6 months following initiation of sulphonylurea therapy.

\section{Biochemical analyses}

In all patients, peripheral venous blood samples were collected between 7-8 a.m. following an overnight 12-hour fast. Glucose was measured by glucoseoxidase method, lipids were measured by routine enzymatical methods (kits provided by ERBA-Lachema, Czech Republic), and HbAlc was measured using an immunoturbidimetric method (Roche Diagnostica, France).

\section{Genotyping of CDKAL1 rs7756992 (A>G)}

Genomic DNA was extracted using Wizard Genomic DNA purification kit (Promega Corp., Wisconsin, USA). CDKAL1 rs7756992 polymorphism was determined by melting analysis of small amplicon (56 bp) after the real-time PCR on LightScanner 32 instrument (Idaho Technology Inc., Salt Lake City, USA). PCR was performed in a total volume of $10 \mu \mathrm{l}$ containing $1 \mathrm{x}$ LCGreen Plus (Idaho Technology Inc.), $0.2 \mathrm{mM}$ dNTPs, $3 \mathrm{mM} \mathrm{MgCl}_{2}$, $250 \mathrm{ng} / \mu \mathrm{l} \mathrm{BSA}, 0.9 \mu \mathrm{M}$ each primer (forward, 5' -AATTAATATTCCCCCCTGTATTTTAGT-3'; 
reverse, 5'-GCTCATTGCTACATAACTGTAGAT-3'), 1 UBioThermAB polymerase with corresponding buffer (GeneCraft, Münster, Germany), and approximately $10 \mathrm{ng}$ DNA. PCR conditions were as follows: initial denaturation at $95{ }^{\circ} \mathrm{C}$ for $5 \mathrm{~min}, 60$ cycles at $95{ }^{\circ} \mathrm{C}$ for $10 \mathrm{~s}, 52^{\circ} \mathrm{C}$ for 15 $\mathrm{s}$ and $72{ }^{\circ} \mathrm{C}$ for $15 \mathrm{~s}$. Amplification was immediately followed by melting analysis starting with denaturation at $95{ }^{\circ} \mathrm{C}$ for $1 \mathrm{~min}$, and renaturation at $40{ }^{\circ} \mathrm{C}$ for 1 minute. Data were acquired over $60-95{ }^{\circ} \mathrm{C}$ range at the thermal transition rate of $0.05{ }^{\circ} \mathrm{C} / \mathrm{s}$. Genotypes were identified by different melting temperatures (homozygotes) or by change in the melting curve shape (heterozygotes), as indicated on the derivative plots using LightScanner 32 software version 1.0.0.23. Sensitivity and specificity was evaluated by testing 10 samples of each genotype (previously genotyped by PCR-RFLP method) in parallel (two replicates). All testing samples were successfully amplified, and all software-based genotype assignments corresponded with previous genotype assignments, thus, we reached $100 \%$ sensitivity and specificity. When genotyping the patient samples, melting controls (one for each genotype) were used in each run.

\section{Statistical analyses}

Statistical analyses were performed using SPSS 17.0 for Windows software (SPSS Inc., Chicago, IL, USA). Relative frequencies were compared using the $\chi^{2}$-test. Continuous variables are presented as mean \pm standard error of mean (S.E.). For comparison of means either unpaired or paired Student's t-test, Wilcoxon rank test, analysis of variance (ANOVA) or ANOVA on ranks were used as appropriate. Multivariate general linear models were used to account for baseline differences and other confounding factors for the two primary outcomes change in FPG $(\triangle \mathrm{FPG})$ and HbAlc $(\triangle \mathrm{HbA} 1 \mathrm{c})$ after treatment. All models were adjusted for age, gender, BMI, metformin dose, sulphonylurea dose and either for baseline FPG or baseline $\mathrm{HbAlc}$ values.

\section{Results}

In the entire group of 101 patients with type 2 diabetes 6-month sulphonylurea treatment lead to highly significant average reduction in $\mathrm{HbAlc}$ and fasting glycemia by $1.1 \%$ and $1.48 \mathrm{mmol} / \mathrm{l}$, respectively. Significant differences were recorded also in LDL cholesterol, HDL cholesterol and triglycerides levels after sulphonylurea treatment. Small and non-significant increase of body weight and BMI was observed (Table 1).
Table 1. Baseline characteristics of the subjects and the effect of 6-month sulphonylurea treatment in addition to previous metformin monotherapy in the entire group of patients.

\begin{tabular}{lccc}
\hline & $\begin{array}{c}\text { Before } \\
\text { treatment }\end{array}$ & $\begin{array}{c}\text { After } \\
\text { treatment }\end{array}$ & p \\
\hline $\begin{array}{l}\text { Weight } \\
(\mathrm{kg})\end{array}$ & $84.8 \pm 16.1$ & $85.1 \pm 16.1$ & 0.28 \\
BMI & $30.3 \pm 4.0$ & $30.4 \pm 4.0$ & 0.68 \\
$\left(\mathrm{~kg} / \mathrm{m}^{2}\right)$ & & & \\
$\begin{array}{l}\text { FPG } \\
\text { (mmol/l) }\end{array}$ & $8.66 \pm 1.41$ & $7.18 \pm 1.21$ & $<0.001$ \\
$\begin{array}{l}\text { HbAlc } \\
(\%)\end{array}$ & $8.07 \pm 1.00$ & $6.97 \pm 0.60$ & $<0.001$ \\
$\begin{array}{l}\text { Cholesterol } \\
\text { (mmol/l) }\end{array}$ & $5.06 \pm 1.21$ & $4.88 \pm 1.21$ & 0.17 \\
$\begin{array}{l}\text { LDL cholesterol } \\
\text { (mmol/l) }\end{array}$ & $2.83 \pm 0.91$ & $2.60 \pm 0.60$ & 0.027 \\
$\begin{array}{l}\text { HDL cholesterol } \\
\text { (mmol/l) }\end{array}$ & $1.11 \pm 0.30$ & $1.16 \pm 0.30$ & 0.031 \\
$\begin{array}{l}\text { Triglycerides } \\
\text { (mmol/l) }\end{array}$ & 1.94 & 1.86 & 0.003 \\
\hline
\end{tabular}

Data are expressed as mean \pm S.D. or median $\left[25^{\text {th }}, 75^{\text {th }}\right.$ percentile]. $p$-values refer to paired Student's tests or Wilcoxon rank test. BMI, body mass index; FPG, fasting plasma glucose; LDL, low-density lipoprotein; HDL, high-density lipoprotein.

The distribution of CDKAL1 rs7756992 genotypes followed Hardy-Weinberg equilibrium. 49 subjects were homozygous for the A-allele (AA genotype), 36 were carriers of one G-allele (AG genotype), and 16 were homozygotes for the G-allele (GG genotype).

Baseline clinical and biochemical characteristics, as well as the indices of glycemic control after sulphonylurea treatment of three genotype groups are displayed in Table 2. No significant differences were observed in gender representation, age, weight, BMI, diabetes duration, baseline total cholesterol, LDLcholesterol, HDL-cholesterol, triglycerides, FPG, and HbA1c levels among the genotype groups. After 6-month sulphonylurea treatment FPG levels were significantly different among the three groups, with the lowest mean values in patients with GG genotype $(\mathrm{p}=0.046)$. Post hoc analysis showed that the difference in FPG after treatment was significant between $\mathrm{AG}$ and AA genotypes $(p=0.03)$ and borderline significant between $G G$ and AA genotypes $(p=0.05)$. This result provided a rationale for pooling the subjects with $\mathrm{AG}$ and GG genotypes in the subsequent analysis. 
Table 2. Clinical and biochemical characteristics of the subjects according to CDKAL1 rs7756992 genotypes.

\begin{tabular}{lcccc}
\hline & $\mathbf{A A}$ & $\mathbf{n G}$ & $\mathbf{G G}$ & $\mathbf{n}=\mathbf{1 6}$ \\
& $\mathbf{n}=\mathbf{4 9}$ & $\mathbf{n = 3 6}$ & $9 / 7$ & 0.28 \\
\hline Gender (males/females) & $27 / 22$ & $14 / 22$ & $59.8 \pm 10.80$ & 0.48 \\
Age (years) & $63.1 \pm 11.9$ & $61.3 \pm 7.20$ & $2.7 \pm 2.0$ & 0.79 \\
Diabetes duration (years) & $2.5 \pm 2.8$ & $2.2 \pm 1.8$ & $86.7 \pm 10.4$ & 0.51 \\
Weight (kg) & $86.5 \pm 16.8$ & $82.7 \pm 15.0$ & $30.4 \pm 2.4$ & 0.97 \\
BMI (kg/m) & $30.7 \pm 4.2$ & $30.6 \pm 4.8$ & $2165 \pm 334^{\mathrm{c}, \mathrm{d}}$ & 0.028 \\
Metformin dose (mg) & $1875 \pm 325$ & $1872 \pm 392$ & $38.5 \pm 17.2^{\mathrm{e}}$ & 0.032 \\
Sulphonylurea dose (\% max.) & $51.5 \pm 17.4$ & $44.4 \pm 19.8$ & $8.47 \pm 1.44$ & 0.84 \\
FPG (mmol/l) - baseline & $8.70 \pm 1.40$ & $8.60 \pm 1.44$ & $6.83 \pm 1.16^{\mathrm{b}}$ & 0.045 \\
FPG (mmo/l) - after therapy & $7.48 \pm 1.12$ & $6.94 \pm 1.14 \mathrm{a}^{\mathrm{a}}$ & $7.60 \pm 0.88$ & 0.10 \\
HbAlc (\%) - baseline & $8.10 \pm 0.91$ & $8.17 \pm 1.02$ & $6.75 \pm 0.72$ & 0.14 \\
HbAlc (\%) - after therapy & $7.07 \pm 0.49$ & $6.90 \pm 0.60$ & $5.37 \pm 1.20$ & 0.27 \\
Total cholesterol (mmol/l) & $5.20 \pm 0.63$ & $4.94 \pm 1.14$ & $3.00 \pm 0.20$ & 0.23 \\
LDL cholesterol (mmol/l) & $2.68 \pm 0.42$ & $2.86 \pm 0.36$ & $1.10 \pm 0.20$ & 0.73 \\
HDL cholesterol (mmol/l) & $1.09 \pm 0.21$ & $1.14 \pm 0.36$ & $1.95[1.41 ; 2.40]$ & 0.42 \\
Triglycerides (mmol/l) & $2.00[1.80 ; 2.30]$ & $1.90[1.55 ; 2.23]$ & & \\
\hline
\end{tabular}

Data are expressed as mean \pm S.D. or median $\left[25^{\text {th }}, 75^{\text {th }}\right.$ percentile]. $p$-values refer to ANOVA, ANOVA on ranks or chi-squared test (for gender). Pairwise post hoc comparisons: ${ }^{a} p=0.03$ vs. $A A,{ }^{b} p=0.05$ vs. $A A ;{ }^{c} p=0.012$ vs. $A A ;{ }^{d} p=0.017$ vs. $A G ;{ }^{e} p=0.015$ vs. $A A$. $B M I$, body mass index; FPG, fasting plasma glucose; LDL, low-density lipoprotein; HDL, high-density lipoprotein.

Table 3. Effect of sulphonylurea treatment on glycemic control with respect to $C D K A L 1$ genotypes - dominant model.

\begin{tabular}{|c|c|c|c|}
\hline & $\begin{array}{c}\mathbf{A A} \\
n=49\end{array}$ & $\begin{array}{c}\mathbf{A G}+\mathbf{G G} \\
\mathbf{n}=52\end{array}$ & p \\
\hline FPG (mmol/l) - baseline & $8.70 \pm 1.40$ & $8.56 \pm 1.30$ & 0.61 \\
\hline $\begin{array}{l}\text { FPG }(\mathrm{mmol} / \mathrm{l})-\text { after } \\
\text { therapy }\end{array}$ & $7.48 \pm 1.12$ & $6.90 \pm 1.08$ & 0.013 \\
\hline$\triangle F P G(\mathrm{mmol} / \mathrm{l})$ & $1.02 \pm 1.33$ & $1.48 \pm 1.51$ & $0.022 *$ \\
\hline HbAlc (\%)-baseline & $8.10 \pm 0.91$ & $7.99 \pm 0.94$ & 0.61 \\
\hline $\begin{array}{l}\text { HbAlc }(\%)- \\
\text { after therapy }\end{array}$ & $7.07 \pm 0.49$ & $6.85 \pm 0.65$ & 0.074 \\
\hline$\triangle H b A l c(\%)$ & $1.03 \pm 0.70$ & $1.19 \pm 0.79$ & $0.244^{*}$ \\
\hline
\end{tabular}

Data are displayed as mean \pm S.D., p-values refer to unpaired Student's tests or general linear models*: $\triangle F P G$ and $\triangle \mathrm{HbA}_{1 c}$ means were adjusted in general linear models for gender, age, BMI, sulphonylurea dose, metformin dose and baseline FPG or $\mathrm{HbA}_{1 \mathrm{c}}$ values, respectively. FPG, fasting plasma glucose; BMI, body mass index.

Thus, in further analysis, dominant genetic model was tested in which carriers of the G-allele $(\mathrm{AG}+\mathrm{GG})$ were compared with AA genotype subjects (Table 3). After sulphonylurea therapy, patients in the AG+GG group achieved significantly lower FPG levels in comparison with patients with the AA genotype (6.90 \pm 1.08 vs. $7.47 \pm 1.12 \mathrm{mmol} / \mathrm{l}, \mathrm{p}=0.013)$. Consequently, adjusted $\triangle \mathrm{FPG}$ was significantly higher in the $\mathrm{AG}+\mathrm{GG}$ compared to the AA group (1.48 $\pm 1.33 v s$. $1.02 \pm 1.51 \mathrm{mmol} / \mathrm{l}, \mathrm{p}=0.022)$. Similar trend was observed for HbAlc levels, but the difference between the genotype groups did not reach the level of statistical significance (Table 3).

\section{Discussion}

In the present study we have shown that the carriers of the G-allele of the CDKAL1 rs7756992 gene variant responded by significantly higher reduction in fasting glycemia to treatment with sulphonylurea in comparison with patients homozygous for A-allele.

To our best knowledge, the present finding is the first to provide an evidence on differences in the FPG reductions between various CDKAL1 genotype groups. Although some dysbalance in both metformin and sulphonylurea dosage was observed among the genotype groups, statistical adjustement for treatment doses of both drugs in multivariate analysis did not change the significance of association between CDKAL1 genotype and FPG reduction with sulphonylurea treatment. 
The mechanism underlying the effects of CDKAL1 polymorphism on the therapeutic effect of sulphonylureas is unknown. Groenewoud et al. (2008) and Stančáková et al. (2008) reported that a CDKAL1 variant (rs7754840) was related to decreased first-phase insulin secretion but not to second-phase insulin secretion during hyperglycemic clamps and intravenous glucose tolerance tests, respectively. In an in vitro study, OharaImaizumi et al. (2010) found that panceatic $\beta$-cells from mice with knocked-out CDKAL1 gene had a reduced first-phase insulin release. Their results also indicate that CDKAL-1 controls first-phase insulin exocytosis in $\beta$-cells by facilitating ATP generation, $\mathrm{K}_{\mathrm{ATP}}$ channel responsiveness and the subsequent activity of $\mathrm{Ca}^{2+}$ channels through pathways other than previously hypothesized CDK5-mediated regulation (OharaImaizumi et al. 2010). Since $C D K A L 1$ influences $\mathrm{K}_{\mathrm{ATP}}$ channel responsiveness, this mechanism could explain modulation effect of sulphonylureas on glycemic control by $C D K A L 1$ variant.

There are limitations in the current pilot study such as the small size of the study group. However, approximately $30 \%$ difference in $\triangle \mathrm{FPG}$ after 6-month therapy between the homozygous carriers of the A-allele of the CDKAL1 rs7756992 gene polymorphism and the patients with the $A G+G G$ genotype suggests that the sample size of this study, although limited, is enough to gain understanding on the role of CDKAL1 polymorphisms in the pharmacologic response to sulphonylureas. Furthermore, although the duration of the present study was longer compared to the previous ones (Zhang et al. 2007, Feng et al. 2008), our results reflects only the effect of sulphonylurea therapy during the first six months after initiation of this treatment. Therefore, our results cannot be automatically extrapolated beyond this period. Nevertheless, in the GoDARTS study, higher probability of sulphonylurea failure was observed up to 12 months following initiation of therapy in patients with the risk TCF7L2 genotypes (Pearson et al. 2007). Therefore, CDKAL1 genotype related differences in glucose lowering response to sulphonylureas observed in the present study might be preserved beyond six months. Further studies are needed to address this question. Importantly, investigation of a homogenous group of patients with type 2 diabetes, in whom sulphonylurea was started in a typical clinical situation after metformin monotherapy failure, represents a strength of the present study.

In conclusion, the present pilot study showed for the first time that the variation in $C D K A L 1$ gene is related to therapeutic response to sulphonylurea treatment. Large-scale pharmacogenetic studies are needed to confirm the associations of diabetes associated gene variants with therapeutic effects of antidiabetic drugs. Such observations might lead in the future to the development of genotype-based personalized strategies for the treatment of type 2 diabetes.

\section{Conflict of Interest}

There is no conflict of interest.

\section{Acknowledgements}

This study was supported by research grants VEGA 1/0380/10 and VEGA 1/0112/11 from the Ministry of Education, Science, Research and Sport of the Slovak Republic, and by the project "Center for Excellent Research of Atherosclerosis", Operational Program Research and Development funded by the European Regional Development Fund (30 \%).

\section{References}

DEHWAH MAS, WANG M, HUANG QY: CDKAL1 and type 2 diabetes: a global meta-analysis. Genet Mol Res 9: 1109-1120, 2010.

FENG Y, MAO G, REN X, XING H, TANG G: Ser1369Ala variant in sulfonylurea receptor gene $A B C C 8$ is associated with antidiabetic efficacy of gliclazide in Chinese type 2 diabetic patients. Diabetes Care 31: 1939-1944, 2008.

GRIBBLE FM, REIMANN F: Sulphonylurea action revisited: the post cloning era. Diabetologia 46: 875-891, 2003.

GROENEWOUD MJ, DEKKER JM, FRITSCHE A, REILING E, NIJPELS G, HEINE RJ, MAASEN JA, MACHICAO F, SCHAFER SA, HARING HU, HART LM, VAN HAEFTEN TW: Variants of CDKAL1 and IGF2BP2 affect first-phase insulin secretion during hyperglycemic clamps. Diabetologia 51: 1659-1663, 2008.

KIRCHHOFF K, MACHICAO F, HAUPT A, SCHÄFER SA, TSCHRITTER O, STAIGER H, STEFAN N, HÄRING H-U, FRITSCHE A: Polymorphisms in the TCF7L2, CDKAL1 and SLC30A8 genes are associated with impaired proinsulin conversion. Diabetologia 51: 597-601, 2008. 
NATHAN DM, BUSE JB, DAVIDSON MB, FERRANNINI E, HOLMAN RR, SHERWIN R, ZINMAN B; AMERICAN DIABETES ASSOCIATION; EUROPEAN ASSOCIATION FOR THE STUDY OF DIABETES: Management of hyperglycaemia in type 2 diabetes: a consensus algorithm for initiation and adjustment of therapy. A consensus statement from the American Diabetes Association and the European Association for the Study of Diabetes. Diabetologia 49: 1711-1721, 2008.

OHARA-IMAIZUMI M, YOSHIDA M, AOYAGI K, SAITO T, OKAMURA T, TAKENAKA H, AKIMOTO Y, NAKAMICHI Y, TAKANASHI-YANOBU R, NISHIWAKI C, KAWAKAMI H, KATO N, HISANAGA S, KAKEI M, NAGAMATSU S: Deletion of CDKAL1 affects mitochondrial ATP generation and first-phase insulin exocytosis. PLoS One 5: e15553, 2010.

PALMER ND, GOODARZI MO, LANGEFELD CD, ZIEGLER J, NORRIS JM, HAFFNER SM, BRYER-ASH M, BERGMAN RN, WAGENKNECHT LE, TAYLOR KD, ROTTER JI, BOWDEN DW: Quantitative trait analysis of type 2 diabetes susceptibility loci identified from whole genome association studies in the Insulin Resistance Atherosclerosis Family Study. Diabetes 57: 1093-1100, 2008.

PEARSON ER, DONELLY LA, KIMBER C, WHITLEY A, DONEY SF, MCCARTHY MI, HATTERSLEY AT, MORRIS AD, PALMER CN: Variation in TCF7L2 influences therapeutic response to sulfonylureas. A GoDARTs Study. Diabetes 56: 2178-2182, 2007.

RIDDERSTRALE M, GROOP L: Genetic dissection of type 2 diabetes. Mol Cell Endocrinol 297: 10-17, 2009.

SAXENA R, VOIGHT BF, LYSSENKO V, BURTT NP, DE BAKKER PI, CHEN H, ROIX JJ, KATHIRESAN S, HIRSCHORN JN, DALY MJ, HUGHES TE, GROOP L, ALTSHULER D, ALMGREN P, FLOREZ JC, MEYER J, ARDLIE K, BENGTSSON B, BOSTROM K, ISOMAA B, LETTRE G, LINDBLAD U, LYON HN, MELANDER O, NEWTON-CHEC C, NILSSON P, ORHO-MELANDER M, RASTAM L, SPELIOTES EK, TASKINEN MR, TUOMI T, GUIDUCCI C, BERGLUND A, CARLSON J, GIANNINY L, HACKETT R, HALL L, HOLMKVIST J, LAURILA E, SJOGRN M, STERNER M, SURTI A, SVENSSON M, TEWHEY R, BLUMENSTIEL B, PARKIN M, DEFELICE M, BARRY R, BROEDEUR W, CAMARATA J, CHIA N, FAVA M, GIBBONS J, HANSAKER B, HEALY C, NGUYEN K, GATES C, SOUGNES C, GAGE D, NIZZARI M, GABRIEL SB, CHIRM GW, MA Q, PARIKH H, RICHARDSON D, RICKE D, PURCELL S: Genome-wide association analysis identifies loci for type 2 diabetes and triglyceride levels. Science 316: 1331-1336, 2007.

SCHRONER Z, JAVORSKY M, TKACOVA R, KLIMCAKOVA L, DOBRIKOVA M, HABALOVA V, KOZAROVA M, ZIDZIK J, RUDIKOVA M, TKAC I: Effect of sulphonylurea treatment on glycaemic control is related to TCF7L2 genotype in patients with type 2 diabetes. Diabetes Obes Metab 13: 89-91, 2011.

SCOTT LJ, MOHLKE KL, BONNYCASTLE LL, WILLER CJ, LI Y, DUREN WL, ERDOS MR, STRINGAM HM, CHINES PS, JACKSON AU, PROPKUNINA-OLSSON L, DING CJ, SWIFT AJ, NARISU N, HU T, PRUIM R, XIAO R, LI XY, CONNEELY KN, RIEBOW NL, SPRAU AG, TONG M, WHITE PP, HETRICK KN, BARNHART MW, BARK CW, GOLDSTEIN JL, WATKINS L, XIANG F, SARAMIES J, BUCHANAN TA, WATANABE RM, VALLE TT, KINNUNEN L, ABECASIS GR, PUGH EW, DOHENY KF, BERGMAN RN, TUOMILEHTO J, COLLINS FS, BOEHNKE M: A genome-wide association study of type 2 diabetes in Finns detects multiple susceptibility variants. Science 316: 1341-1345, 2007.

STANČÁKOVÁ A, PIHLAJAMAKI J, KUUSISTO J, STEFAN N, FRITSCHE A, HARING H, ANDREOZZI F, SUCCURRO E, SESTI G, BOESGAARD TW, HANSEN T, PEDERSEN O, JANSS PA, HAMMARSTEDT A, SMITH U, LAAKSO M; EUGENE2 CONSORTIUM: Single-nucleotide polymorphism rs 7754840 of CDKAL1 is associated with impaired insulin seeretion in nondiabetic offspring of type 2 diabetic subjects and in a large sample of men with normal glucose tolerance. J Clin Endocrinol Metab 93: 1924-1930, 2008.

STEINTHORSDOTTIR V, THORLEIFSSON G, REYNISDOTTIR I, BENEDIKTSSON R, JONSDOTTIR T, WALTERS GB, STYRKASDOTTIR U, GRETARSDOTTIR S, EMILSSON V, GHOSH S, BAKER A, SNORRADOTTIR S, BJARNASON H, NG MC, HANSEN T, BAGGER Y, WILENSKY RL, REILLY MP, ADEYEMO A, CHEN Y, ZHOU J, GUDNASON V, CHEN G, HUANG H, LASHLEY K, DOUMATEY A, SO WY, MA RC, ANDERSON G, BORCH-JOHNSEN K, JORGENSEN T, VAN VLEIET-OSTAPTCHOUK JV, HOFKER MH, WIJMENGA C, CHRISTIANSEN C, RADER DJ, ROTIMI C, GURNEY M, CHAN JC, PEDERSEN O, SIGURDSSON G, GULCHER JR, THORSTEINSDOTTIR U, KONG A, STEFANSSON K: A variant in CDKAL1 influences insulin response and risk of type 2 diabetes. Nat Genet 39: 770-775, 2007. 
TAKEUCHI F, SERIZAVA M, YAMAMATO K, FUJISAWA T, NAKASHIMA E, OHNAKA K, IKEGAMI H, SUGIYAMAT, KATSUYA T, MIYAGISHI M, NAKASHIMA N, NAWATA H, NAKAMURA J, KONO S, TAKAYANAGI R, KATO N: Confirmation of multiple risk loci and genetic impacts by a genome-wide association study of type 2 diabetes in the Japanese population. Diabetes 58: 1690-1699, 2009.

WHEELER E, BARROSO I: Genome-wide association studies and type 2 diabetes. Brief Funct Genom 10: 52-60, 2011.

ZEGGINI E, WEEDON MN, LINDGREN CM, FRAYLING TM, ELLIOT KS, LANGO H, TIMPSON NJ, PERRY JR, RAYNER NW, FREATHY RM, BARRETT JC, SHIELDS B, MORIS AP, ELLARD S, GROVES CJ, HARRIES LW, MARCHINI JL, OWEN KR, KNIGHT B, CARDON LR, WALKER M, HITMAN GA, MORIS AD, DONEY AS; WELLCOME TRUST CASE CONTROL CONSORTIUM (WTCCC), MCCARTHY MI, HATTERSLEY AT: Replication of genome-wide association signals in UK samples reveals loci for type 2 diabetes. Science 316: 1336-1341, 2007.

ZHANG H, LIU X, KUANG H, YI R, XING H: Association of sulfonylurea receptor 1 genotype with therapeutic response to gliclazide in type 2 diabetes. Diabetes Res Clin Pract 77: 58-61, 2007. 